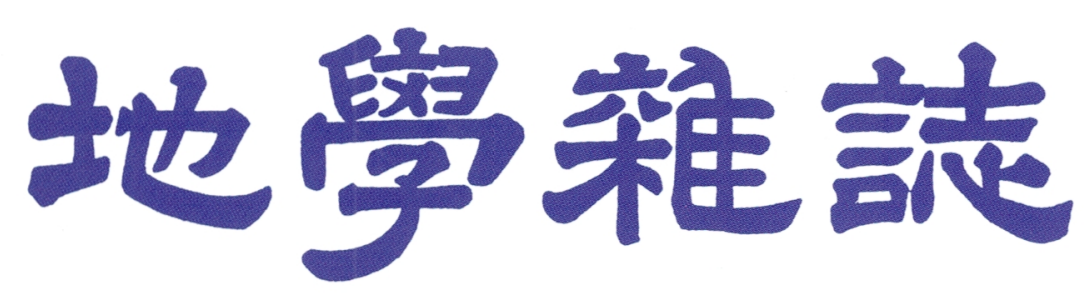

\title{
JOURNAL OF GEOGRAPHY
}

\section{東京地学協会}

TOKYO GEOGRAPHICAL SOCIETY

Founded in 1879

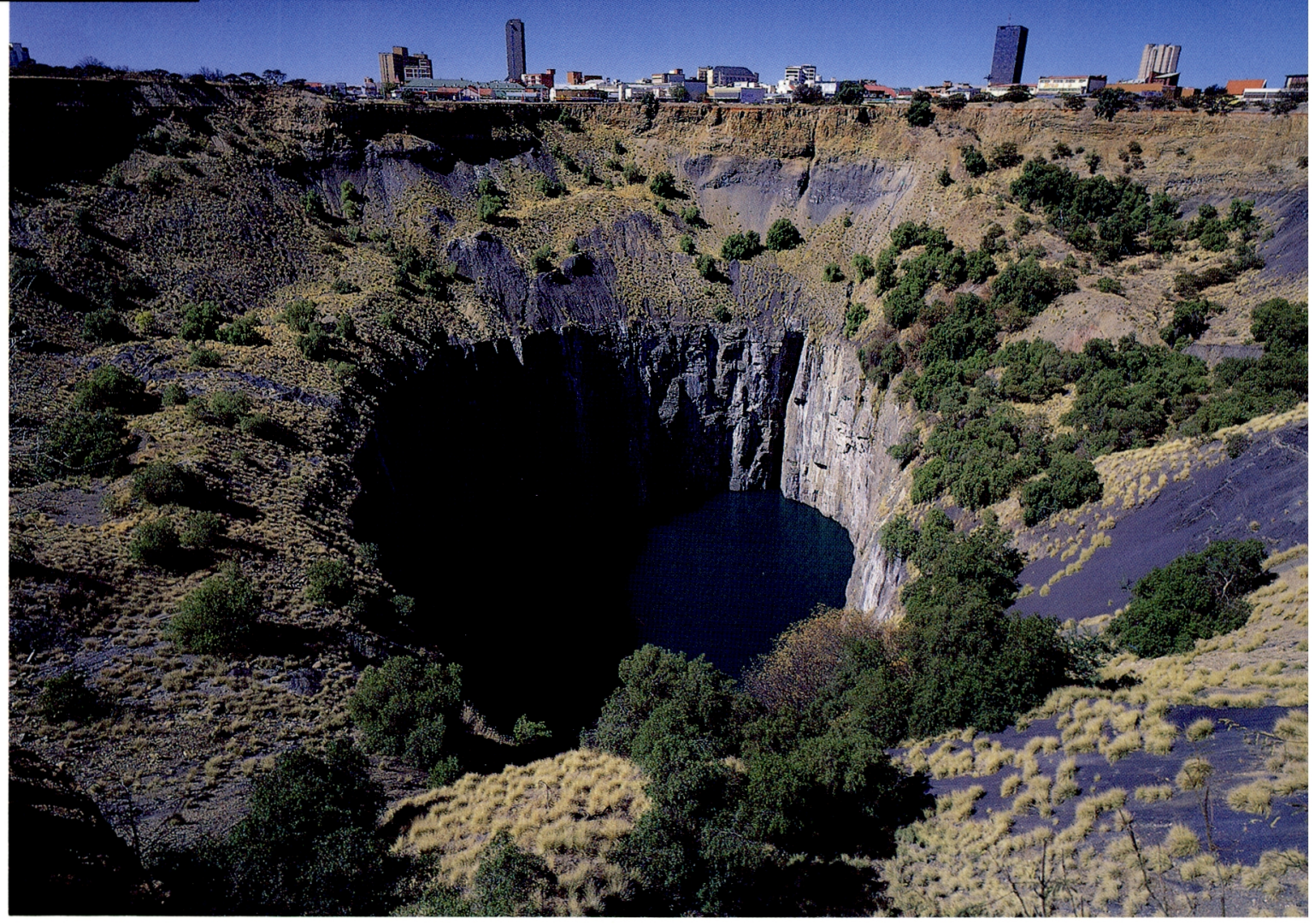

\section{VOL. 110}

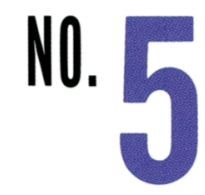




\section{表紙写真}

\section{キンバリー・ダイヤモンド鉱山（南アフリカ）}

\section{The Kimberley Diamond Mine（South Africa）}

ダイヤモンドは深さ 150 ～ $400 \mathrm{~km}$ の上部マントルで誕生し, 周囲のマグマとともに高速で地上に運ばれた火山噴火 の産物キンバーライト中に発見される.このような火山噴火の跡は, 地下に太古代 (25 億年より古い) の地殼抢よびマ ントルが存在する古い大陸の中央部で発見されることがほとんどで, 大きなダイヤモンドを含むキンバーライトの噴火 は 10 億〜 5000 万年前に起きている.

写真は, 1871 年に発見されたダイヤモンドの一大産地キンバリー鉱山の跡地である．直径 $500 \mathrm{~m}$, 深さ $1073 \mathrm{~m}$ （も との穴底は水面下にある) で, 人類が機械を使わずに掘った最深の穴といわれ，ビックホールの愛称で呼ばれている. 1914 年に閉山するまで, ここからは 1450 万カラット（1 カラットは $0.2 \mathrm{~g} ）$ のダイヤモンドが採掘された。

一大産地とはいっても $10 \mathrm{t}$ あたりの土砂にわずか数グラムのダイヤモンドが含まれるに過ぎず, 採掘された土砂から ダイヤモンドを選別・加工・取引するのには多くの人手がかかる.キンバリー鉱山周辺にはダイヤモンド鉱山が次々に 発見され，ダイヤモンド産業にかかわる多くの人々が集まり，現在では人口 17 万人のキンバリー市となっている.

(写真・文：白尾元理 Motomaro SHIRAO) 